\title{
A Critical Analysis of EMERgEnCy MANAgEMEnT
}

\author{
Heather Wyatt-Nichol \\ Stephen F. Austin State University \\ Charles F. Abel \\ Stephen F. Austin State University
}

\begin{abstract}
This article examines the underlying assumptions, imagery, and ideology of the discourse on emergency management that emerged among politicians, the media, and political appointees following Hurricane Katrina. The purpose is to investigate the extent to which they constituted an effective framework for thinking through, talking about, evaluating, and engaging with emergencies. It is our intent to systematically reveal the underlying assumptions, goals, values, and beliefs embedded in this particular discourse with a view toward understanding how this discourse delimited and shaped our understanding and expectations of emergency management by government agencies.
\end{abstract}

There was plenty of scapegoating in the immediate aftermath of Hurricane Katrina. Local governments blamed the state and federal government; state government officials blamed the local and federal government; federal government officials blamed the state and local governments; and on occasion, all levels of government blamed the victims themselves. New Orleans Mayor Nagin was criticized for waiting too long to order a mandatory evacuation, failure to adhere to the city's emergency plan, and failure to use the estimated 200 school buses to evacuate citizens who were unable to leave the city on their own. Governor Blanco was criticized for being reluctant to transfer power to the federal government. Although she requested federal assistance on the day Katrina made landfall, Blanco originally declined a White House proposal to place control of National Guard troops under the federal government. She blamed the federal government for failing to fulfill promises of provisions for supplies and personnel. At the federal level the administration was criticized for initially failing to recognize the 
magnitude of the disaster and the desperate situation of residents along the Gulf Coast.

This paper suggests that we must move beyond scapegoating to consider how both political and media discourse not only limits and shapes our understanding and expectations of emergency management, but dominates administrative discourse as well. Of course, public administration is, at bottom, a political endeavor. That policy-making depends upon how a law, or an executive order, or a judicial decision is put into practice, and that administrative practice depends upon the interpretation of those laws, orders, and decisions by public administrators is so obvious that professions of shock at the idea are hard to credit. But, as Wilson explained, "the real function of Administration is not merely ministerial, but adaptive, guiding, discretionary. . . . It must accommodate and realize the law in practice" (quoted in Miewald, 1984, pp. 2526). To fulfill this proper function, public administration requires "large powers and unhampered discretion" (Wilson, 1887/1966, p. 373) that neither politicians, nor legislatures, nor even courts "should. . .be suffered to manipulate" (Wilson, 1887/1966, p. 371). This paper argues that, to the contrary, in contexts of emergency, administrative expertise and discretion are not only hampered and manipulated by political discourse, but dominated as well. Toward demonstrating this thesis, we will examine the discourses of emergency management that emerged among politicians, the media, and political appointees to the extent that they constitute a framework for thinking through, talking about, evaluating, and engaging with emergencies. We will then indicate how public management discourse echoes the media and political discourse rather than adapting and guiding those discourses toward the public good.

Managers and administrators should be interested in examining the emergency discourses of politicians, political appointees, and the media not merely because such an examination can make plain the relationships of dominance and subservience that these discourses establish among those groups, between these groups and public administrators, and between these groups and the public. They also should be interested because understanding how these discourses work can serve as a method for critiquing existing administrative theories and managerial practices in ways that might demonstrate how the arguments offered in support of a particular rule, procedure, concept, or principle might actually undermine their goals and aspirations. Second, such a discourse analysis can show how doctrinal arguments are informed by and disguise ideological thinking. This can be of value not only to the practitioner who seeks to reform existing regimes, but also to the theorist. 
Third, such an examination offers both a new kind of interpretive strategy and a critique of conventional interpretations of statutory texts relevant to emergency situations.

For the moment, we will neglect the latter interest in favor of the prior three. This bias derives from the fact that normative theorizing is a complex and multi-vocal pursuit in itself; a pursuit that deserves more consideration than can be given here where we are interested in beginning to describe and explain the power relationships, assumptions, and values as revealed in discourse that may lead us astray in emergency decision-making. We pay particular attention to those discourses that are popular in the media, prevalent among politicians, and predominant amidst appointees rather than those discourses circulating in career service circles. This bias derives, first of all, from the fact that "success in government consists of not just making the right decisions, but also of mobilizing political support for the decision" (Thomas, 1996, p. 13). Consequently, external discourses provide "more of a challenge for the public manager than for his private-sector counterpart"; and as he or she must "balance the conduct of external political relations with numerous outside actors and institutions" (Thomas, 1996, p. 13), he or she must contend more assiduously with those discourses than must any private sector counterpart as well. And, finally, the fact is that even such "normal" practices of the public servant as planning, staffing, budgeting, and purchasing are subject to a range of similar external constraints. Hence, more of a focus on external discourses within the organization's environment is required when describing and explaining decision-making in the public sector.

\section{DISCOURSE ANALYSIS}

Discourse analysis, as we employ the term, takes "language as a form of social practice" (Fairclough, 1989, p. 20) and examines how social and political domination is reproduced by text and talk. The basic idea is "that language connects with the social through being the primary domain of ideology, and through being both a site of, and a stake in, struggles for power" (Fairclough, 1989, p.15). Discourse analysis does not provide a tangible answer to any problem engendered by relationships of dominance and subservience. Rather, it enables us to gain access to the ontological and epistemological assumptions behind a relationship, a statement, a practice or a policy. Methodologically, discourse analysis is not limited to either specific procedures or specific kinds of text or talk as it is interested in all relationships of dominance and "there is no power relation without the correlative constitution of a 
field of knowledge, nor any knowledge that does not presuppose and constitute at the same time power relations" (Foucault, 1975/1977, p. 27). Rather any approach that systematically explores how social practices and individual consciousness are discursively shaped, manipulated, and formed constitutes useful discourse analysis (MacDonell, 1986).

For our purposes we will take "discourse" most broadly. That is, we will understand "discourse" as any system of signs, whether spoken, written, or otherwise, that reflect social practice. Critical discourse analysis reveals the ways through which social and political domination are reinforced and extended through a system of signs in speech, written texts, images, or spectacle. Spectacle, image, and written and spoken language, as discourse, shape and define our understanding of disaster. What counts as a disaster, expectations for response, and whether or not such response was effective is defined and interpreted by active and passive participants alike. In short, the meaning is jointly produced. As a result, the typical discourses surrounding disasters may be analyzed systematically.

\section{APPLICATION}

The techniques and procedures of discourse analysis seek to accomplish these ends through a "meticulous, scholarly, serious, responsible. . .account of. . something in the text that tends to drop out of view" (Caputo, 1997, p. 77). That something is the array of hidden assumptions, hegemonies, inconsistencies, contradictions, and parameters of our discourse. Bringing this array to light, discourse analysis explores its implications by revealing the ambiguity of our concepts, principles, and categories, the contradictions in our discursive regimes, and the necessary bias of our accepted processes of thinking about, producing, and representing what counts as knowledge, fact, or truth. To accomplish these ends, we must explore the discourse for what it marginalizes or excludes. In this regard, we must examine especially any statements, in addition to proffered hierarchies, that purport to admit of no legitimate disagreement; and we must attend to metaphors, imagery, and analogies that carry multiple levels of meaning. And in the process, we must imagine any exceptions to the envisioned outcomes, any paradigmatic scenarios, or any models for behavior or theorizing that are proffered as "professional," rational, or pragmatic. Then, we must read between the lines for what is not said, not pictured, or not desired. In these ways, we may identify the actual objective(s) of the speaker (conscious or unconscious) as opposed to the claims made in the discourse itself. And finally, we must rewrite the scripts, scenarios, and models by inverting 
the hierarchies, including the excluded, focusing on the marginalized, saying what is not said, imagining what is not pictured, and reevaluating what is not desired. In brief, we must develop a new perspective, a perspective that includes both the socio-culturally and politically accepted perspective and what that perspective leaves in the shade of whatever light it casts.

\section{THE IMAGERY PORTRAYED BY THE MEDIA AND THE BUSH ADMINISTRATION}

To begin our analysis, then, let us first look at the imagery employed in the discourse on Katrina. Imagery is a powerful force in framing discourse. The way in which disasters are represented in the media influences and shapes our understanding of such events. As representations and forms of entertainment, spectacles have the ability to influence political life and often result in power struggles over the control of the imagery that is presented to the public at large (Gotham, 2007). As Fox and Miller (2005) suggest, the increasing number of news sources, the 24/7 coverage, the disregard for journalistic standards among Internet media, and the infotainment provided by the major networks crowd out investigative reporting, construct a hyper-reality, and provide little helpful information; they instead favor sensationalized speculation and innuendo. In this context, Hurricane Katrina was portrayed dramatically and intensely as an invincible natural disaster eliciting anti-social behaviors among the populace, confounding the experts, and revealing the incompetence of authorities. Reports, in brief, became sensationalized, focused on the power struggles among politicians, and turned tragedy into entertainment. For example, Geraldo Rivera, no stranger to the infotainment industry, tearfully pleaded on the Fox News show Hannity \& Colmes, "Yesterday the sun set on a scene of terror, chaos, confusion, anarchy, violence, rapes, murders, dead babies, dead people-I mean, it was-I could not emphasize how horrible it was 24 hours ago, 24 hours later" (as quoted on Hannity, 2005, September 3).

As part and parcel of the constructed hyper-reality, mainstream media coverage of Katrina also echoed a hegemonic discourse as news stories perpetuated racial stereotypes, particularly when African Americans were portrayed as incapable of self sufficiency, or worse, as ruthless criminals. These reports reflected and reinforced racial stereotypes of light skinned individuals as heroes and dark skinned individuals as either victims or perpetrators but never proactive or positive agents (Watkins, 2006). There were images, for example, of armed Korean merchants, portrayed as upholding the spirit of entrepreneurship 
amid chaos and lawlessness as they protected their stores from looting and destruction at the hands of African American residents (Martinas \& Luft, 2006). In fact, while most news stories portrayed African Americans as looters, Caucasians were portrayed as getting supplies (Gotham, 2007). Furthermore, stories coming out of the Superdome in New Orleans portrayed individuals, the majority of which were African Americans, as violent predators, as reports on assaults, murder, and rape were perpetuated. There were stories of babies who had their throats slit, of a seven-year-old girl who was raped and then murdered in the Superdome, and corpses laid out amid the excrement in the convention center (Young, 2005). The reports of rape and murder were never substantiated.

Partially in light of the imagery coming out of the Gulf and partially to control the image of the federal government, the Bush administration quickly began to work on portraying the federal government as perhaps the only responsive, professional, and effective actor in the drama. Hence, in the immediate aftermath of the hurricane, appearance became more important than substance as federally-directed efforts were depicted as spectacularly successful. In order to save face, image repair was deployed through a variety of strategies ranging from denial and evasion to corrective action and mortification as presidential speeches on the subject of Katrina employed several themes including, "compassionate president, major devastation, optimism, commander in chief, and religious invocation" (Liu, 2007, p.42). Michael Brown was told to roll up his sleeves in order to appear to be "more hard working" (Gotham, 2007, p. 88). The Coast Guard, under federal direction, was reported to have evacuated "over six times the number in an average year-earning themselves the name the 'New Orleans Saints.'" Federal Emergency Management Agency's (FEMA) urban search and rescue teams were also reported to have "performed exceptionally well" (Townsend, 2006, p. 38), regardless of the lack of planning, training, and equipment.

What were suppressed by these images were real emancipatory opportunities. Crowded to the margins of discourse were "opposing movements to offer competing interpretations of reality that challenge the status quo" (Gotham, 2007, p. 86). As Habermas (1981/1987) might have predicted, both the potential for social control made possible by the one-sided communication flows characteristic of mass media, and the communication structures themselves, served to contain what challenges occurred. And what is most interesting is that, at least in the immediate aftermath of the disaster, interests challenging the official 
rendition of events were marginalized by the mass media until it faced opposition from the print media and the "blogosphere; and it was this turn of events, as Habermas also might have predicted, that pressured the mass media to fulfill its duty to professional journalism.

One point worth stressing at this juncture is that the effect of the print media and the "blogosphere" on the discourse was pivotal. There is no doubt that much of the American public relies on electronic media as their main source of news. With the exception of former FEMA director Michael Brown and the residents without power in the Gulf Coast region, many citizens watched frustrated residents waiting at the Superdome, waiting to be rescued from their rooftops, and waiting on even the obliteration of entire communities in Mississippi and Alabama. Written media, however, was not completely overshadowed by the electronic media as evident in the number of reporters from major newspapers assigned to the region. And this coverage provided to the American public both ignited and shaped public debate on a variety of issues including government response and social injustice as reporters for the print media worked to debunk the myths and distortions that occurred during the first few days after Katrina. The majority of articles published in the American Journalism Review over the past few months, for example, address issues of inaccuracy and how to avoid it in the future (O'Mahony, 2005). Finally, the assertion that technical developments in electronic media do not necessarily result in centralized networks was supported by the fact that web logs often broke news stories and sometimes served as a check on electronic news stories.

\section{HIERARCHIES AND OPPOSITIONS}

By way of continuing our analysis, we next examine how the emergency management discourse was used to reinforce, replicate, and challenge power relations and dominance in the aftermath of Katrina. As the literature suggests, experts attempted to exercise a form of dominance over the populace; and the people were in this way "subjectified" (Garland, 1997) in order to assure compliance through the advice that was put forth as the most rational course of action given the circumstances (Foucault, 1988). In exercising this dominance experts attempted to regulate "conduct according to particular rationalities" (Foucault, 1979, as cited in Eide \& Knight, 1999, p. 540). For example, predominately, the responses called for by the media, the administration, and its appointees, emphasized objectification or "putting Katrina in Perspective," (Townsend, 2006), technical skills (Cockburn, 1985), rationality (Knights \& Richards, 2003), control, and manipulation 
(Kerfoot \& Knights, 1993), over benevolence, compassion, and any emotional commitment to taking care of the victims of disaster.

With this in mind, it is helpful to peruse the current discourse on Katrina as revealed in the White House report (Townsend, 2006) on that hurricane and the discourse of various officials and experts as they responded to both the media and the House and Senate committees. Taking the report as a whole, we begin by noting that current emergency management discourse on Katrina proceeds by way of first identifying what is good or bad, determining its causes, and assigning fault for its occurrence. Next, considerable effort is expended on discussing what, if anything, should be done, changed, or left alone. Finally, a program for achieving what should be done is elaborated, identifying the agents, the advocates, and the adversaries of change, and anticipating what must be done in response to the probable behavior of each in order to advance the program accurately, efficiently, and fairly. Though couched carefully in terms of the unique and overwhelming nature of the storm, the White House report nevertheless embodies both this emphasis and the attempt to exercise dominance that follows from it. First, local people were depicted as responding irrationally (i.e., not in the public interest or even in the interest of their own survival). For example, security problems were not blamed on a lack of preparedness at the state and federal levels, but on the local population. Security problems in the Gulf Coast were described as obstructing federal response relief efforts, including search and rescue missions, communications, and the provision of medical support:

The lawlessness also delayed restoration of essential private sector services such as power, water, and telecommunications. Federal officials attempted to have law enforcement officers protect emergency responders against security threats. However, due to a lack of planning, arranging this support took several days, during which the situation grew worse. (Townsend, 2006, p. 40)

Similarly, state and local officials were charged with a lack of competence. The Mayor of New Orleans and the Governor of Louisiana were criticized for failing to have a post-landfall evacuation plan. The Mayor was also depicted as incapable of managing local efforts effectively, chastised for failed emergency response communication networks, and berated for the lack of "incident command structures" (Townsend, 2006), regardless of the fact that one of the first places affected by flooding was the 911 communications dispatch center.

The reality, of course, was that although the National Response Plan of 2004 provides the Department of Homeland Security broad authority 
to respond to major disasters through search and rescue efforts and the provision of necessary resources, the government response to Hurricane Katrina revealed problems of interagency cooperation, coordination, and communication at not only the local and state levels, but the federal level as well. The strained relations between organizations that generally result from competition for funding, personnel, and policy priority were heightened by the disaster, making it more difficult to coordinate response efforts (Koehler, 1995). Not surprisingly, the recommendation from the White House was an increased role for the Department of Homeland Security and the Environmental Protection Agency, despite the report's recognition that at the federal level "there is no overarching plan" for search and rescue as the National Response Plan focuses only on urban search and rescue (Townsend, 2006).

\section{WHAT IS HIDDEN}

As a third step in analysis, it is helpful to consider what was hidden by the official rendition of the Katrina disaster. The discourse as framed by the White House report, for example, sought to put "Katrina in Perspective" by claiming that it was an extremely rare event:

\footnotetext{
Hurricane Katrina was the most destructive natural disaster in U.S. history. . .vastly exceeded that of any other major disaster. . . . Seventy-five hurricanes of Katrina's strength at landfall-a category three-have hit the mainland United States since 1851. . . Katrina was anything but a "normal" hurricane. . . . Hurricane Camille, a Category 5 storm, had wind speeds that exceeded those of Katrina upon landfall, but Camille's winds only extended seventy-five miles from its center, whereas Katrina's extended 103 miles. (Townsend, 2006, p. 5)
}

In this sort of narrative, "the facts are structured in such a way that they become components in a particular story" (Campbell, 1998, p. 34), a story that establishes an order of meaning in the narrated events. In brief, the facts were structured in such as way that Katrina was a story about events that could not be foreseen. By implication, officials and experts could only be expected to manage well those emergencies that fit their knowledge derived from contextually specific interpretations of the past. As hurricanes like Katrina were unknown, the "unforeseeable danger" language rendered Katrina hypothetical, rather than statistically certain, as it truly was. With discourse focused on likely events, as opposed to the statistical certainty that Katrina would happen sooner or later, the risks in question were rendered understandably less worrisome to the point of being considered irrational to consider. 


\section{THE EXCLUDED: INSTITUTIONAL AND CLASS RESPONSIBILITIES}

It is important in analysis not only to seek what is hidden but also to look at what is excluded. In this regard, we might examine statements in the discourse that in addition to proffering hierarchies also purport to admit of no legitimate disagreement. The most prevalent of these, for example, exhibit a clear "ethos of individualism" (Calás \& Smircich, 1992, p. 233). This can be seen clearly in the focus upon concepts such as motivation and leadership; concepts that assume "an autonomous, acultural, and ahistorical self" (Calás \& Smircich, 1992, p. 233). By focusing on the autonomous self, this discourse tends to de-emphasize the relational and bureaucratically-structured cultural/psychological aspects of emergency management, including conflict within and among levels of government, conflict within and among social classes, and the cultures of power and influence operating among both bureaucrats and between bureaucrats and the public. It favors, instead, scapegoating. This ethos is demonstrated clearly in the White House report's recommendation that "earlier presidential involvement could have speeded the response" because he alone could have cut through all bureaucratic resistance" (Hsu, 2006, p. 01). Similarly, during Senate hearings on the disaster, Chertoff blamed Brown, and Brown blamed Chertoff (Bacon, 2006). New Orleans Mayor Ray Nagin later blamed Louisiana Governor Blanco (Russell, 2005), and a subsequent House report blamed them both.

This ethos of individualism requires that government officials and purported experts proclaim themselves, however tacitly, capable of foreseeing chains of events that, in reality, are plagued by indeterminacy. Emergencies, in other words, must make a transition discursively from the abstract to the seemingly concrete (Ericson \& Haggerty 1997). The problem is that such discursive proclamations hide the indeterminacy that is incompatible with the ethos. This discourse situation reveals the exploitative possibilities in bureaucratic relationships generally. As individuals attempt to meet organizational demands of legitimacy, professionalism, public trust, problem solving competency, and political viability, they may, in disaster situations, compete to avoid blame. They discover themselves, suspended in between uncertainty and insecurity (Townley, 1994) as they seek to portray themselves as meeting the continually changing demands of authority figures and the public (Willmott, 1994). To accomplish this they may seek to exploit the vulnerabilities of others in the organization. 


\section{IDEOLOGICAL DISCOURSE CONSTRAINTS: THE LIMITS AND IMPLICATIONS OF RUGGED INDIVIDUALISM}

This ethos of individualism also reflects certain elements of conservative ideology, particularly the belief in a smaller government and a limited federal role. Generally speaking, conservative Republicans favor tax reductions, deregulation, and reduced spending on domestic social programs. These conservative values have been reflected in the operations and management of disaster preparedness and response, particularly at the federal level, in previous and current administrations. One former FEMA director referred to disaster assistance as "an oversized entitlement program" and argued that "disaster victims should rely on 'faith-based organizations' rather than the government for help" (Schneider, 2005, p. 516).

This emphasis on individualism and faith-based organizations promotes a version of the American dream in which individual success is based on motivation alone. This version is more prevalent in America than in other democracies as Americans are more likely to believe success is based on individual efforts and accomplishments rather than the class structure into which they were born (Bok, 1996). Hence it is more typical of our society to adopt and to find convincing a discourse blaming the individual-even in cases of devastating natural disastersrather than the political, economic, or social institutions wherein the individual is embedded. Two consequences of this "pull yourself up by the bootstraps" mentality include, first, the belief that government assistance perpetuates dependency and second, the tendency to blame the victim. Such assumptions are manifested in both media coverage and organizational responses to Katrina.

Statements on "personal responsibility," for example, often overlap with statements blaming the victim. The statement issued by Secretary of Homeland Security Michael Chertoff on September 1, 2005, and restated by former FEMA director Michael Brown the very next day is a case in point: "The critical thing was to get people out of [New Orleans] before the disaster. Some people chose not to obey that order. That was a mistake on their part" (Gotham, 2007, p. 91). Similarly, Pennsylvania Senator Rick Santorum, asserted:

You have people who don't heed those warnings and then put people at risk as a result of not heeding those warnings. There may be a need to look at tougher penalties on those who decide to ride it out and understand that there are consequences to not leaving. (Democratic Party Blog, 2005, September 7) 
In reality, of course, it is essential to recognize that poverty does not exist in the absence of wealth. When the "personal responsibility" discourse is employed it is usually in reference to what the poor should be doing to help themselves. Rarely does it speak of any personal responsibility of the rich to help either the victims of disaster or the poor.

The conservative ideological ethos self-help is evident in disaster planning as well as disaster response. Although there may be a general consensus that individuals should attempt to be minimally prepared for a disaster; it is necessary to recognize that many individuals lack the financial resources to stock up on extra supplies. Anyone who has ever lived on a limited income through either a minimum wage job or government assistance would understand this. Unfortunately, most midlevel and executive managers occupying positions in emergency management organizations come from the limited discourse of middle-toupper class America.

Many large charities and government organizations are staffed by white, middle-class people. Until such entities have workers and volunteers who actually look, speak, and understand the world from the many vantage points of those affected by natural disasters, it will be difficult to adequately serve non-white, non-middle class communities. Class, race, and ethnic bias are endemic in major relief organizations and this will continue to be the case until there are massive shifts in diversity. (Park \& Miller, 2006, p. 19)

Most hurricane evacuation plans are based on the flawed assumptions that individuals have the financial resources and transportation to leave when a mandatory evacuation is ordered. This was particularly evident in the evacuation plans of Hurricane Katrina. Both the Secretary of Homeland Security and the director of FEMA were oblivious to the fact that the majority of those who "chose" to stay behind did not really have a choice at all. They did not have the means, transportation or otherwise, to make it out of the city.

\section{DOMINANT PUBLIC MANAGEMENT DISCOURSE}

In his call for a science of administration, Wilson (1966) maintained that administration is business and that politics should (and could) be removed from the administration of government. Asserting that administration is a science and that the same principles in carrying out official duty are the same in any system of government or business, Wilson (1966) states, "This is why there should be a science of administration which shall seek to straighten the paths of government, to make its business less unbusinesslike" (p. 372). The flawed assumption of the polit- 
ics-administration dichotomy is that public administrators operate in an organizational world isolated from the external influence of politics. Organizational discourse within public agencies is influenced by external forces, particularly those from the political arena. Public managers are subject to a variety of constraints imposed by the executive and legislative branches. The power to develop organizational policy and response is a reflection of, and the result of, the political environment in which an administrator operates. Therefore, a focus on external discourses within the organization's environment is required when describing and explaining decision-making in the public sector.

The influence of business on public administration discourse is evident as market values have dominated the field in recent decades through a variety of initiatives, including New Public Management and Reinventing Government. According to Box (2004), "Increasingly, public administration practitioners and academicians are faced with demands from politicians and citizens that government should be operated like a business" (p. 199). Advocates of New Public Management contend that the emphasis on rules and hierarchical structure, as main principles of bureaucracy, led to the displacement of goals where the achievement of results became less important than maintaining the rules and processes of the organization. The dominance of the New Public Management discourse was reinforced through the reinvention movement of the 1990s, which advocated the position that government was too large and was bogged down by excessive rules and regulations, and that public agencies were no longer efficient or effective in the provision of services. Asserting that government should be run more like a business, Osborne and Gaebler (1993) emphasized the need for performance measurement and alternative service delivery options such as contracting out or complete privatization. During that same year former Vice President Gore's reinvention initiative was established through the National Performance Review (NPR). The overall goal of NPR was to create a government that "works better and costs less" through strategies of downsizing and performance based measurement.

The application of the principles of the New Public Management model was achieved, in part, through passage of the Government Performance Results Act of 1993 (GPRA). The legislation required federal agencies to develop mission statements, identify goals and objectives, and measure performance through a variety of outcome indicators. It is questionable whether GPRA initiatives have resulted in more efficient and effective public organizations. An assessment of FEMA offers evidence that such efforts were not successful. In fact, the very same initia- 
tives designed to increase efficiency and effectiveness of government organizations may have contributed to the ineffective response of the federal government to Hurricane Katrina. As mandated by the GPRA, a mission statement was developed and performance measurement was implemented within FEMA. The mission statement of FEMA is "to reduce the loss of life and property and protect the nation from all hazards, including natural disasters, acts of terrorism and other manmade disasters" (Government Accountability Office, 2007, p. 16). FEMA also uses the baseline approach to benchmark performance of organizational goals. For example, the goal of FEMA's (2006) Public Assistance program, designed to help those in need after major disasters, is "to provide and deliver program assistance efficiently, effectively, and consistently with increased customer satisfaction."

FEMA's 1998 customer satisfaction survey serves as a baseline to benchmark performance on a variety of objectives related to the goal of providing public assistance after disasters. Performance objectives include: the obligation of $50 \%$ of the funding within 90 days of a disaster declaration, $80 \%$ of funding within 180 days of declaration, and the closure of public assistance for $90 \%$ of disasters within two years of the original declaration date (FEMA, 2006). Based upon these measures alone, the agency might claim adequate performance during Hurricane Katrina. This is evidence that bureaucratic rationalization has resulted in a disconnect between citizens and the organizations designed to serve them since most will agree that FEMA's response to Hurricane Katrina was neither efficient nor effective. Such over-emphasis on quantitative measures once again contributes to the problem of appearance over substance where "it is now more important to show you did your job than to actually do your job" (Miller \& Fox, 2007, p. 12).

While advocates of New Public Management contend that government organizations should emulate private sector businesses, proponents of reinvention go a step further and contend that alternative service delivery options, such as contracting out or complete privatization of various public services, are necessary. These reform initiatives are based on the assumption that open and competitive bidding occurs. However, this is often not the case. As Miller and Fox (2007) note, "One should not expect free competition where there are numerous examples of single-bid contracts, negotiated bids, wired deals, outright bribery, and 'profit'-sharing kick-back schemes for anyone who reads the newspapers to know about" (p. 35). In the aftermath of Katrina, nearly half of the contracts awarded for reconstruction were awarded without competitive biding and none of the contracts provided that lo- 
cal companies should be given priority (Lotke \& Borosage, 2006). Corporations already working in Iraq, however, were awarded new contracts in Gulf Coast restoration. Halliburton received a total of $\$ 125$ million in reconstruction contracts (Halliburton Watch, 2005); Blackwater received $\$ 33$ million in government security contracts; and Titan Corporation, then defending lawsuits stemming from its activities in Iraq's Abu Ghraib prison and charged by a federal inspector general with overcharging for its services, was awarded contracts for relief work (Lotke \& Borosage, 2006).

Unfortunately, neither the New Public Management initiatives mandated through the GPRA nor reinvention initiatives such as contracting out contributed to effective response to Hurricane Katrina. The perpetuation of power inequities between the actual customer and the perceived customer provides some explanation for the failed efforts. As Farmer (1995) notes:

The real customer of an agency is the legislative or other body that sponsors and funds the agency. The customer-oriented improvement plans are inclined to fail because the improvements are designed within the context of the same basic situation of power inequality between the bureaucracy and the customer. (p. 233)

For example, concerned with compliance, reporting, and ultimately funding, the unintended consequence of GPRA is that the real customer for FEMA is Congress, not the general public. In comparison, contracting out has even more potential to extend such power inequities as the demands of business are imposed on both the political and administrative arenas of government. When recovery, response, and reconstruction efforts become profitable then markets in disaster management emerge. Klein (2007) contends that the military-industrial complex has "morphed into what is best understood as a disaster-capitalism complex" (p. 50). Furthermore:

Once a market has been created, it needs to be protected. The companies at the heart of disaster-capitalism complex increasingly regard both the state and nonprofits as competitors; from the corporate perspective, whenever governments or charities fulfill their traditional roles, they are denying contractors work that could be performed at a profit. (Klein, 2007, p. 52)

The influence of business on politics and administration is pervasive. 


\section{CONCLUSION}

To the dismay of some managers and administrators, analysis does not offer quick solutions for the practitioner. Nor is it the intent of analysis to offer prescriptive solutions such as a ten-step process to improve disaster preparedness and response. Nevertheless, scholars and practitioners alike benefit by examining the underlying assumptions, imagery, and ideology of dominant discourses. Overall, analysis advances public administration theory by exposing power inequities reflected in dominant discourses and by challenging us to think about how we interpret and understand events, in this case, the imagery and response to Hurricane Katrina. In its starkest form, our argument is that political leaders and media pundits are in a position of (qualified) dominance vis-à-vis both the victims of Katrina and public administration professionals as they enjoy the resources necessary to impose a particular DISCOURSE concerning emergency management upon the victims and the career professional alike. In its briefest terms, our concern is that as reality is defined by discourse, as discourse is the negotiation of truth, and as discourse is controlled by those in power, those in power control the truth, at least in matters of emergency management.

\section{REFERENCES}

Bacon, P. (2006, February 15). Chertoff versus Brown, round two. Time.com. Retrieved March 27, 2007, from http://www.time.com/time/nation/article/0, $8599,1159948,00 . h t m l$

Bok, D. (1996). The state of the nation: Government and the quest for a better society. Cambridge: Harvard University Press.

Box, R. C. (2004). Public administration and society: Critical issues in American governance. Armonk: M. E. Sharpe.

Calás, M., \& Smircich, L. (1992). Using the "F" word: Feminist theories and the social consequences of organizational research. In A. Mills \& T. Tancred (Eds.), Gendering organizational analysis (pp. 222-234). London: Sage.

Campbell, D. (1998). National deconstruction: Violence, identity, and justice in Bosnia. Minneapolis: University of Minnesota Press.

Caputo J. (1997). Deconstruction in a nutshell: A conversation with Jacques Derrida. New York: Fordham University Press.

Cockburn, C. (1985). Machinery of dominance: Women, men, and technical know-how. London: Pluto.

Democratic Party Blog. (2005, September 7). GOP blame the victims chorus: Official membership. Retrieved May 1, 2007, from http://www.democrats. org/a/2005/09/gop_blame_the_v.php 
Ericson, R. V., \& Haggerty, K. D. (1997). Policing the risk society. Toronto: University of Toronto Press.

Fairclough, N. (1989). Language and power. London: Longman.

Farmer, D. J. (1995). The language of public administration: Bureaucracy, modernity, and postmodernity. Tuscaloosa: University of Alabama Press.

Federal Emergency Management Association. (2006). Performance goals. Retrieved May 12, 2007, from http://www.fema.gov/government/grant/pa/ goals.shtm

Foucault, M. (1977). Discipline and punish: The birth of the prison (A. Sheridan, Trans.). New York: Pantheon. (Original work published 1975)

Foucault, M. (1988). Politics and reason. In M. Foucault, Politics, philosophy, culture: Interviews and other writings (pp. 57-85). New York: Routledge.

Foucault, M. (1979). Governmentality: Ideology and Consciousness (vol. 6). In Eide, M. \& Knight, G. (1999). Service journalism and the problems of everyday life. European Journal of Communication, 14(4), 525-547.

Fox, C. J., \& Miller, H. T. (2005). All Monica all the time: Crowding out the public discourse. Administrative Theory \& Praxis, 27, 486-497.

Garland, D. (1997). "Governmentality" and the problem of crime: Foucault, criminology, sociology. Theoretical Criminology, 1, 173-214.

Gotham, K.F. (2007). Critical theory and Katrina: Disaster, spectacle, and immanent critique. City, 11, 81-99.

Government Accountability Office. (2007). Homeland security: Preparing for and responding to disasters (GAO Publication No. GAO 07-395T). Washington, DC: U.S. Government Printing Office.

Habermas, J. (1987). The theory of communicative action (vol. 2): Lifeworld and system: A Critique of Functionalist reason (T. McCarthy, Trans.). Boston: Beacon Press. (Original work published 1981)

Halliburton Watch. (2005, October 12). Halliburton gets another $\$ 33$ million for Hurricane Katrina clean-up. Retrieved May 12, 2007, from http://www. halliburtonwatch.org/news/katrina2.html

Hannity, S. (Executive Producer). (2005, September 3). Hannity \& Colmes [Television broadcast]. New York: Fox News.

Hsu, S. (2006, February 12). Katrina report spreads blame. Washingtonpost. com. Retrieved March 21, 2007, from http://www.washingtonpost.com/ wpdyn/content/article/2006/02/11/AR2006021101409.html

Kerfoot, D., \& Knights, D. (1993). Management, manipulation, and masculinity: From paternalism to corporate strategy in financial services. Journal of Management Studies, 30, 659-677.

Klein, N. (2007, October). Disaster capitalism: The new economy of catastrophe. Harpers Magazine, 47-58. 
Knights, D., \& Richards, W. (2003). Sex discrimination in UK academia. Gender, Work, and Organization, 10, 213-238.

Koehler, G. A. (1995). What disaster response management can learn from chaos theory. California Research Bureau Conference Proceedings. Sacramento: California Research Bureau.

Liu, B. F. (2006). President Bush's major post Katrina speeches: Enhancing image repair discourse theory applied to the public sector. Public Relations Review, 33, 40-48.

Lotke, E., \& Borosage, R. L. (2006). Hurricane Katrina: Natural disaster, human catastrophe. Washington, DC: Campaign for America's Future. Retrieved April 15, 2007, from http://home.ourfuture.org/reports/stl_con failure_katrina.pdf

MacDonell, D. (1986). Theories of discourse: An introduction. Oxford: Basil Blackwell.

Martinas, S., \& Luft, R. (2006). Toward the just restoration of New Orleans: Readings on racism and resistance before, during, and after Katrina for solidarity activists. Retrieved January 17, 2007, from http://www.common groundrelief.org/files/packet\%20for\%20web2.doc

Miewald, R. D. (1984). The origins of Wilson's thought: The German tradition and the organic state. In J. Rabin \& J. S. Bowman (Eds.), Politics and administration (pp. 17-30). New York: Marcel Dekker.

Miller, H. T., \& Fox, C. J. (2007). Postmodern public administration (Rev. ed.). Armonk, NY: M. E. Sharpe.

O'Mahony, C. (2005). Media under fire in post-Katrina storm. The Post.IE. Retrieved March 8, 2007 from http://archives.tcm.ie/businesspost/2005/10/09/ story8601.asp\#

Osborne, D., \& Gaebler, T. (1993). Reinventing government: How the entrepreneurial spirit is transforming the public sector. New York: Plume.

Park, Y., \& Miller, J. (2006). The social ecology of Hurricane Katrina: Rewriting the discourse of "natural" disasters. Smith College Studies in Social Work, 76(3), 9-24.

Russell, G. (2005, October 23). Nagin gets mixed reviews. The Times-Picayune. Retrieved March 8, 2007, from http://www.nola.com/frontpage/tp/index. ssf?/base/news-4/113005056877980.xml

Schneider, S.K. (2005). Administrative breakdowns in the governmental response to Hurricane Katrina. Public Administration Review, 65, 515-516.

Thomas, P.G. (1996). Beyond the buzzwords: Coping with change in the public sector. International Review of Administrative Sciences, 62, 5-29.

Townley, B. (1994). Reframing human resource management. London: Sage.

Townsend, F. (2006). The federal response to Hurricane Katrina: Lessons learned [the White House report]. Washington, DC: U.S. Government 
Printing Office. Retrieved January 17, 2007, from http://www.whitehouse. gov/reports/katrina-lessons-learned.pdf

Watkins, B. (2006, August 25). PRWeb: Press release newswire. Retrieved March 21, 2007, from http://www.prweb.com/releases/2006/8/prweb428816.htm.

Willmott, H. (1994). Bringing agency (back) into organizational analysis: Responding to the crisis of (post) modernity. In J. Hassard \& M. Parker (Eds.), Towards a new theory of organizations (pp. 87-130). London: Routledge.

Wilson, W. (1966). The science of administration. In A. S. Link (Ed.), The papers of Woodrow Wilson, vol. 5 (pp. 371-374). Princeton, N.J.: Princeton University Press. (Original Work published in 1887)

Young, G. (2005, September 6). Murder and rape-fact or fiction? The Guardian. Retrieved April 15, 2007, from http://www.guardian.co.uk/katrina/ story $/ 0,16441,1563532,00 . \mathrm{html}$

Heather Wyatt-Nichol is an Assistant Professor at Stephen F. Austin State University in Nacogdoches, Texas. She has written articles on contingent employment in the public sector and integrating law enforcement training with university education. Her research interests include organizational behavior, organizational justice, social equity, and ethical climates.

Charles F. Abel is the Chair of the Department of Political Science, Geography, and Public Administration at Stephen F. Austin State University in Nacogdoches, Texas. He is the author of books and articles in the fields of public law, international political economy, and public administration theory. 
Copyright of Administrative Theory \& Praxis is the property of University of Nebraska at Omaha, School of Public Administration and its content may not be copied or emailed to multiple sites or posted to a listserv without the copyright holder's express written permission. However, users may print, download, or email articles for individual use. 